\title{
CARLOS ALBERTO MEDEIROS - O PROFESSOR: TESTEMUNHO DE UMA DISCÍPULA
}

CATARINA RAMOS ${ }^{1}$

Escrever sobre Carlos Alberto Medeiros não é tarefa fácil para uma pessoa que, além de sua discípula, a ele está ligada por laços de profunda amizade. Corre-se sempre o risco de os sentimentos se sobreporem à razão que deve presidir a um texto desta natureza. Contudo, e ao contrário do que diz o ditado, acho que o coração tem razões que a razão muito bem conhece, pelo que é numa base de racionalidade e objectividade que procurarei deixar aqui o meu testemunho.

Natural de Ponta Delgada (S. Miguel, Açores), Carlos Alberto Medeiros completou, nesta cidade, a sua formação pré-universitária, em 1960.

Profundamente influenciado por Orlando Ribeiro na sua formação universitária, iniciou a sua actividade docente aos 24 anos, quando em 1966 foi contratado como Assistente de Geografia da Faculdade de Letras da Universidade de Lisboa (F.L.U.L.), onde se tinha licenciado um ano antes com a classificação de 18 valores. Nos dois anos lectivos seguintes acumulou também as funções de docência no curso de Arquitectura da Escola Superior de Belas Artes de Lisboa.

Em 1968 inicia um estágio na Universidade de Bordéus onde desenvolve a sua investigação no âmbito da Geografia Tropical. Dois anos depois, toma posse como Assistente de Geografia da Faculdade de Letras da Universidade de Luanda (Curso de Letras em Sá da Bandeira, actual Lubango), onde permanece até 1974. Regressa à 'casa-mãe' (F.L.U.L.) onde, a partir de 1976, passa a desempenhar as funções de Professor Auxiliar, depois de defender o seu doutoramento em Geografia Humana sobre a Colonização dos Planaltos da Huíla (Angola).

O ano de 1979 é um ano de 'viragem' para Carlos Alberto Medeiros, não só porque é promovido a Professor Catedrático, categoria que desempenha até à sua aposentação em Novembro de 2002; mas também porque redirecciona a sua investigação de África para Portugal. Assim, como investigador do Centro de Estudos Geográficos (C.E.G.), deixa a Linha de Acção ‘Estudos de Geografia

1 Professora Associada da Faculdade de Letras, Universidade de Lisboa. Investigadora do Centro de Estudos Geográficos da Universidade de Lisboa. E-mail: cramos@fl.ul.pt 
das Regiões Tropicais' para passar a integrar a Linha de Acção 'Estudos de Geografia Humana e Regional' (até ao presente), sendo mais tarde director desta área científica, cargo que exerce até 1996.

Conheci o professor Carlos Alberto Medeiros em Novembro de 1977, ainda na sua 'fase tropicalista', quando me inscrevi em Geografia Tropical, disciplina de opção da licenciatura em Geografia. Nessa altura, e com os meus dezanove anos, frequentar essa disciplina era, para mim, quase imperiosa, porque representava uma oportunidade de rever experiências e aprofundar conhecimentos que tinha adquirido durante a minha vivência de 2 anos na África Oriental, bem como de aprender aquilo que não tinha compreendido durante a minha estadia africana. O fascínio pelo 'continente-mãe' foi reavivado nessa disciplina, muito pelo empenho do Prof. Medeiros e pelo à-vontade e interesse com que ele abordava quer as questões de carácter humano quer físico, característica rara num professor universitário. No final da disciplina, os vários grupos de trabalho tinham de fazer uma exposição oral sobre o tema estudado, experiência nova para mim e para os meus colegas do $2 .^{\circ}$ ano. Depois de colarmos no quadro, mapas, figuras e gráficos (naquele tempo o power point era ainda uma miragem e os acetatos coisa rara), o nervosismo era mais que muito nesse nosso baptismo oratório, mas, modéstia à parte, saímo-nos muito bem. Eu agarrei-me ao ponteiro, companheiro amigo, naquela hora difícil, e lá o fui passeando sobre o Senegal, motivo do nosso trabalho. Mal sabia eu que esse momento iria ser decisivo na minha carreira académica, porque desde esse dia, fiquei 'debaixo de olho' do Prof. Medeiros que descobriu em mim uma vocação até então insuspeitada: a da docência.

Se 1979 foi um ano de viragem para Carlos Alberto Medeiros, no que respeita à sua investigação no C.E.G., para mim foi-o também, estando intrinsecamente ligado à sua influência. Foi por sua proposta que passei a ocupar o lugar de tarefeira na Linha de Acção 'Estudos de Geografia Humana e Regional' e que recebi, nessa qualidade, o meu primeiro ordenado das mãos do Dr. Machado Guerreiro (que nessa altura cuidava das finanças do C.E.G.): três notas de quinhentos escudos, motivo de orgulho quando se tem 20 anos. Foi ainda em 1979, depois de ter completado o Bacharelato, e também por proposta do Prof. Medeiros, que passei a ocupar, igualmente, o lugar de monitora do Departamento de Geografia da Faculdade de Letras de Lisboa.

Hoje, 26 anos depois, considero que tive o privilégio de os meus primeiros passos no domínio da investigação científica (guiados não só pelo Prof. Medeiros mas também pela Prof. ${ }^{a}$ Carminda Cavaco, na Linha da Acção citada) terem tido o que é essencial transmitir aos jovens investigadores: apoio e confiança. O apoio ajuda a vencer os obstáculos que vão surgindo e a transformar a inexperiência em experiência; a confiança desenvolve a auto-estima, ajuda a melhorar o desempenho e incentiva a criatividade. Guardarei sempre, desses tempos, a saudade inerente aos bons momentos de trabalho, à troca de ideias e até aos momentos de companheirismo que fui desenvolvendo com o Prof. Carlos Alberto. 
Fui construindo o elenco curricular da minha licenciatura (nessa altura a maior parte das disciplinas era de opção) sempre com o intuito de adquirir uma formação geográfica de base sólida e diversificada, que me proporcionasse uma visão global da ciência geográfica, antes da fase da especialização que a investigação sempre requer. Fui, por isso, frequentando, ora cadeiras de Geografia Física ora de Geografia Humana que me mostraram, na prática, a riqueza interna da ciência geográfica e o seu carácter único na interface das ciências da Terra e da Vida e das ciências Sociais e Humanas.

Carlos Alberto Medeiros sempre apoiou esta minha opção, pensando que, e quando se antevia a possibilidade de continuar a minha carreira universitária, a minha investigação se desenvolvesse na área da Geografia Humana, nessa altura largamente maioritária no gosto dos jovens geógrafos.

Mas, e a vida tem destas coisas, ao longo da licenciatura fui adquirindo uma verdadeira paixão pela Geografia Física (muito pela influência de António de Brum Ferreira, Maria Eugénia Moreira e Ana Ramos Pereira), pelo que, foi com alguma angústia, dado o empenho que ele tinha posto na minha orientação, que lhe comuniquei este facto antes do final da licenciatura. Era, antes de tudo, meu dever de lealdade e honestidade. Pensei, e disse-lho, que ficaríamos amigos como dantes, mas que compreendia que diminuísse ou retirasse o seu apoio a uma eventual prossecução da minha carreira universitária, visto que os nossos objectivos e gostos geográficos eram diferentes. Nunca esquecerei o semblante do Prof. Carlos Alberto, quando lhe revelei a minha preferência pela Geografia Física: um misto de decepção e consternação foi visível.

O que se passou em seguida mostra o carácter do Prof. Carlos Alberto: para grande espanto meu, a sua atitude foi a oposta; não só me incentivou (e instigou nos meses seguintes) a concorrer ao cargo de assistente estagiária do Departamento de Geografia, mas também, caso fosse bem sucedida nesse concurso, que contava comigo na disciplina de Geografia de Portugal e em projectos de investigação em que a Geografia Física e Humana pudessem e devessem estar interligadas.

Nas duas últimas décadas trabalhei com o Prof. Carlos Alberto na leccionação dessa disciplina e, pontualmente, em actividades de investigação no âmbito de C.E.G. Ao longo de todos estes anos sempre recebi dele incentivos, apoio, confiança e amizade. Nem sempre estivemos de acordo nos vários assuntos em que fomos chamados a intervir, mas sempre resolvemos esses diferendos, sem uma altercação ou zanga, na base do respeito mútuo que Carlos Alberto Medeiros sempre cultivou no seio da Universidade.

Foram muitos os que, independentemente das suas orientações geográficas, procuraram e encontraram no Prof. Carlos Alberto o 'porto de abrigo' em que se refugiaram, depois das tempestades que os debates acalorados de ideias, orientações estratégicas e paradigmas sempre provocaram no meio académico.

O legado que ele transmitiu, enquanto professor, derivado do seu excepcional humanismo, no que diz respeito aos valores da tolerância, capacidade de 
ouvir, compreensão e respeito mútuo, bem como da auto-exigência, continua, no que me diz respeito, a ser transmitido às novas gerações de geógrafos.

O Prof. Carlos Alberto Medeiros mostrou-me, ao longo de um quarto de século de convivência, que a ligação mais forte e indestrutível, entre mestre e discípulo, é aquela que se baseia na confiança mútua e na liberdade que deve ser dada a cada um de prosseguir o seu caminho de acordo com as suas preferências. É por isso que, além de sua discípula, tenho o privilégio inestimável da nossa mútua amizade. 